exist, was much less reassuring from the point of view of the central planning recommended in the Uthwatt report and endorsed from all quarters. Much is being done, however, said Lord Reith, with regard to the preparation of designs, and the supply of materials for post-war use, by standardization, economy of design and the use of alternative materials. He hopes to give an account of such activities and to make a more definite statement later, but assured the House that the need and urgency of the problem is realized and that the Government shares his view that the problems of peace are much more serious than the problems of war.

\section{Chemical Society: New President}

Dr. W. H. Mills, recently elected president of the Chemical Society, has for a long time been one of the outstanding figures in the scientific world: his influence on chemistry at Cambridge has been profound. An independent thinker, his researches bear no resemblance to those of his teachers : he founded a 'school', but he never had a 'team'. A paper by Mills is something to be read not only for instruction, but also for the intellectual pleasure it gives. His work on the cyanines, the photographic sensitizing dyes, was. largely responsible for settling their chemistry, to which his former student, Dr. Hamer, has added so much. But it is for his stereochemical work that Mills is best known. In 1910 and 1914, with Miss Bain, he demonstrated the configuration of the doubly linked nitrogen atom, adding compelling evidence in 1923, with Schindler, and in 1931 with Saunders. The proof, with Warren, of the tetrahedral configuration of the ammonium ion compares for elegance with the proof, with Quibell and Lidstone, of the planar configuration of the 4-coordinated platinous and palladous atoms. The resolution of an allene, with Maitland, was also a remarkable achievement.

Mills's stereochemical investigations, in succession, of restricted rotation in naphthalene, quinoline and benzene derivatives, with Elliott, Breckenridge, Kelham and Dazeley are highly important. Reference must also be made to the 'Mills-Nixon' effect; to the mechanics of the Beckmann change ; to a theory of absolute asymmetric synthesis; and to Mills's supreme skill with molecular models, by means of which he never fails to entrance an audience.

\section{Dr. Dorothy Wrinch}

Dr. Dorothy Wrinch has been appointed to a research professorship jointly by Smith, Mt. Holyoke and Amherst Colleges, in Massachusetts, to conduct a lecture and seminar course for advanced students on structure problems in the biological sciences. Dr. Wrinch is widely known for her exploratory work in mathematics, physics and biochemistry. During the past six years she has been working as a research fellow of the Rockefeller Foundation and has made an extensive study of the chemistry and physics of the proteins, the results of which have been published from time to time in NATURE and in other scientific journals. Her research work on the structure of proteins, especially their two-and three-dimensional patterns, has attracted much attention. A distinctive feature of the new approach to the problem of protein structure which is employed by Dr. Wrinch is that it is based on the study of live proteins, while most previous struetural studies have been conducted with dead proteins such as hair and silk, or with proteins which have lost their native configuration. Dr. Wrinch's views on the structure of globular proteins, based on the cyclol hypothesis, have provoked intense controversy, and while they are still by no means generally accepted, the discussion of their implications has provided a valuable demonstration of the interrelations of biology, chemistry, physics and mathematics.

\section{Evaporation in the Sugar Industry}

The first meeting of the session of the Newcomen Society was held on October 8. Two papers were read, the first by Messrs. N. Deerr and A. Brooks dealing with the "Development of Evaporation in the Sugar Industry", and the second by Mr. S. Withington on "Automobiles in 1830". There were three phases in the progress of the practice of evaporation, it was said, the first reaching back to the time when evaporation was conducted over a direct flame, the second phase being marked by the use of steam. heated appliances and the boiling of syrup under reduced pressure, while from this was developed the present practice of multiple-effect evaporation in a series of vessels. The review of Messrs. Deerr and Brooks ranged all over the world, and reference was made to many inventors, manufacturers and plants. One outstanding event was the patenting in 1813 by the Hon. Edward Charles Howard (1774-1816), a cadet of the ducal House of Norfolk, of the vacuum pan, a master patent appearing complete and successful in operation in its first trial. The first crude idea of multiple-effect evaporation was to be found in a patent of 1826. One of the chief improvers of the practice was Norbert Rillieux, who was born at New Orleans in 1806 and died in Paris in 1894. In 1934 persons connected with the sugar industry all over the world placed a tablet to Rillieux in the State Museum in New Orleans. Multiple-effect evaporation is to-day used not only in the sugar industry but also in others in which large quantities of liquids are dealt with.

\section{Influence of War on Surgery}

Mr. V. ZACHARY CoPE gave a Chadwick Lecture on October 7 in which he discussed the influence of war on surgery. Surgery, or the handicraft of healing, he pointed out, has always been an art, but only recently a science. In pre-historic and historic times up to the time when Harvey discovered the circulation of the blood, surgery was a crude art, and for the most part surgeons learnt their lessons on the battle-field. When first there began to be an anatomical and physiological basis for surgery, it was upon the battle-field that trials of various discoveries were made. Antiseptics were given their first big trial in the Franco-Prussian war. Modern wars are upon 